Winter 2005

\title{
Rallying the Armies or Bridging the Gulf: Questioning the Significance of Faith-Based Educational Initiatives in a Global Age
}

Amy Stambach

University of Wisconsin-Madison

Follow this and additional works at: https://www.repository.law.indiana.edu/ijgls

Part of the Education Law Commons, International Law Commons, and the Religion Law Commons

\section{Recommended Citation}

Stambach, Amy (2005) "Rallying the Armies or Bridging the Gulf: Questioning the Significance of FaithBased Educational Initiatives in a Global Age," Indiana Journal of Global Legal Studies: Vol. 12 : Iss. 1 , Article 7.

Available at: https://www.repository.law.indiana.edu/ijgls/vol12/iss1/7

This Symposium is brought to you for free and open access by the Law School Journals at Digital Repository @ Maurer Law. It has been accepted for inclusion in Indiana Journal of Global Legal Studies by an authorized editor of Digital Repository @ Maurer Law. For more information, please contact rvaughan@indiana.edu.

\section{$\Psi$}

JEROME HALL LAW LIBRARY

INDIANA UNIVERSITY

Maurer School of Law
Bloomington 


\title{
Rallying the Armies or Bridging the Gulf: Questioning the Significance of Faith-Based Educational Initiatives in a Global Age
}

\author{
Amy Stambach*
}

\section{INTRODUCTION}

In some segments of the educational policy world, a shift is underway from regarding schools as secular, modernizing institutions, separate from religious organizations, to thinking about schools as "faith-starved" institutions that can benefit financially as well as spiritually from partnering with religious groups. ${ }^{1}$ National and international lending and aid agencies, including the United States Agency for International Development (USAID) and the World Bank, increasingly identify religious organizations as key providers of basic education. $^{2}$ Speaking at a March 2004 interfaith conference in Washington, D.C., World Bank President James D. Wolfensohn remarked that "[t]here needs to be something greater than leadership based on economics or leadership based on military power... What better place to start than with the faiths?"3 In 1998,

* Associate Professor, Departments of Educational Policy Studies and Anthropology, University of Wisconsin-Madison. Ph.D., University of Chicago. I am indebted to Michael Apple, Karen Armstrong, Jean Comaroff, Michael Herzfeld, Adam Nelson, and Kristin Phillips for comments on earlier versions of this article, and to Wayne Branom III for insightful editorial comments. Funding for this study was provided by the Spencer Foundation (grant \#20030048) and the University of Wisconsin, Graduate School Faculty Fund. Any opinions, findings, and conclusions or recommendations expressed in this essay are my own and do not necessarily reflect the views of these agencies.

1. See generally Harry Judge, Faith-Based Schools and the State: Catholics in America, France, and England (2002). See also Katherine Marshall, Development and Religion: A Different Lens on Development Debates, 76 Peabody J. of Educ. 339 (2001); William Dolan, No Child Left Behind's Faith-Based Initiative Provision and the Establishment Clause, 33 J.L. \& Educ. 1 (2004).

2. See James D. Wolfensohn \& George Carey, Foreword to Faith in Development: Partnership Between the World Bank and the Churches of Africa, at vii (Deryke Belshaw et al. eds., 2001); Participation by Religious Organizations in USAID Programs, 69 Fed. Reg. 31773 (June 7, 2004) (to be codified at 22 C.F.R. pts. 202, 205, 211, 226).

3. World Bank President James D. Wolfensohn, Millennium Challenges for Faith and Development: New Partnerships to Reduce Poverty and Strengthen Conservation, Address at the Interfaith Conference of Metropolitan Washington (Mar. 30, 2004), available at http://web.worldbank.org/ WBSITE/EXTERNAL/NEWS/0,contentMDK:20189510 menuPK:34472 pagePK:34370 pi PK:34424 theSitePK:4607,00.html. 
Wolfensohn, together with Archbishop of Canterbury George Carey and His Highness the Aga Khan, convened an interfaith organization called the World Faiths Development Dialogue (WFDD) which, in 2000 at a conference held in Nairobi, Kenya, identified education as a priority area of action in sub-Saharan Africa. ${ }^{4}$

The WFDD is at the lead but not alone in declaring that faith-government partnerships are innovative and cost-effective. Direct reference to religious groups' roles in development work is evident, for instance, in a recent series of U.S. executive orders that establish Offices of Faith-Based and Community Initiatives (OFBCI) in eight offices of government, including USAID. ${ }^{5}$ In a speech linked to the USAID website, ${ }^{6}$ for instance, President George W. Bush announced that he will "support the faith-based and community groups who bring hope and healing to those who need mentors," and he noted that the "qualities of courage and compassion that we strive for in America also determine our conduct abroad."7 The WFDD and OFBCI differ in important ways. The former, for instance, is an advocacy organization; the latter finances and manages development projects. However, as Katherine Marshall, a World Bank officer who served for a time as a WFDD trustee, notes, "The most important similarity [between the WFDD and the Bush Administration Faith-Based Initiative] is the recognition that in many poor or marginal communities, in both the industrialized and the developing worlds, FBOs [faith-based organizations] play important social transformation roles." 8

This article describes the cultural and political context within which one U.S. faith group, the Churches of Christ, operates in public schools in Tanzania. While Churches of Christ does not itself receive funding directly from USAID

4. See The World Bank Group, Development Dialogue, at http://wbln0018.worldbank.org/ developmentdialogue/developmentdialogueweb.nsf/weblinks/YEON-5G4MTK? OpenDocument (last modified Nov. 2003). As this site notes, the World Bank is a key co-sponsor of the WFDD.

5. See White House Office of Faith-Based and Community Initiatives, available at www.whitehouse.gov/government/fbci/executive-orders.html (last visited Dec. 1, 2004). OFBCI have also been established in the Departments of Justice, Labor, Health and Human Services, Housing and Urban Development, Education, Agriculture, and in the Corporation for National Community Services.

6. See http://www.usaid.gov.

7. President George W. Bush, Radio Address of the President to the Nation (Feb. 1, 2003), available at http://whitehouse.gov/news/releases/2003/02/print/20030201.html (last visited Aug. 31, 2004).

8. Marshall, supra note 1 , at 357. 
or the World Bank, its mission represents the kind of work that policy leaders of faith-based initiatives describe as ideal. ${ }^{9}$ It provides educational assistance to teachers and students at underfunded schools; it operates from a vision of ethics and social justice without overtly proselytizing; and its leaders seek to reduce poverty and integrate local communities into a global economy. ${ }^{10}$

At a broader theoretical level, this essay argues that faith-based initiatives provide a specific way of imagining global interactions. Within the cultural scheme of lending and aid agencies, as well as within the conceptual framework of the Churches of Christ missionaries, faith-based initiatives are seen by participants as counteracting the dehumanizing effects of globalization. Religion is seen as providing a moral base upon which to rebuild a de-territorialized global culture, and education is viewed as a counterbalance to growing global economic inequalities." Together, religion and education operate symbolically and instrumentally to motivate and organize nonreligious initiatives. They are used by policymakers and religious leaders alike to inspire a worldwide community that paradoxically lives within, and yet transcends, national and linguistic boundaries and to create a sense of hope for future, better educated citizens. ${ }^{12}$ As Wolfensohn put it, religion and education tear down the "imaginary wall" between developed and undeveloped countries; faith-based initiatives "[transcend] economics" and deal "with the essence of humanity and what is right." ${ }^{13}$ Or as President George W. Bush remarked, "The truth of the matter is that [a sense of purpose] comes when a loving citizen puts their [sic] arm around a brother and sister in need and says, I love you, and God loves you, and together we can perform miracles."'14

9. For statements of ideals and guidelines, see World Faiths Development Dialogue, at www.wfdd.org.uk/aboutus.html; White House Office of Faith-Based and Community Initiatives, Partnering with the Federal Government: Some Do's and Don'ts for Faith-Based Organizations, at http:// www.whitehouse.gov/government/fbci/guidance/partnering.html (last visited Sept. 1, 2004).

10. This information is based on field research I conducted in Tanzania in 2000 and 2002. In a larger sense, information about education and religion in Tanzania reported here comes from research I have conducted in Tanzania at various times over the course of the past 11 years. Hereinafter, observations from field research will be referenced as "Field Research."

11. See generally José Casanova, Religion, the New Millennium, and Globalization, Soc. of ReLtGION, Winter 2001, at 415.

12. See Marshall, supra note 1 , at 357.

13. Wolfensohn \& Carey, supra note 2.

14. President George W. Bush, Remarks by the President at the First White House National Conference on Faith-Based and Community Initiatives (June 1, 2004), available at http:// www.whitehouse.gov/news/releases/2004/06/print/20040601-10.html (last visited Aug. 31, 2004). 
This essay questions the significance of faith-based educational initiatives not in the sense that it argues that visions of faith are wrong or ill-conceived. Quite the contrary, they are, in the Durkheimian ${ }^{15}$ sense, collective representations that people act upon as, and are therefore, real (even as faith may be politicized, as some Churches of Christ members themselves described Bush's policies). ${ }^{16}$ Moreover, in many contexts, including among members of the Churches of Christ and among many Tanzanians, religion and humanity are existentially inseparable ${ }^{17}$ - a point that Wolfensohn suggests when he refers to the "essence of humanity" and that Chak rabarty has made when he writes that "the question of being human involves the question of being with gods and spirits."18 Rather, at issue here is the singularly harmonious portrayal of religion in a global age. Statements of policy overlook or downplay the fact that people hold competing views of religion and of what faith-based educational organizations should do, and they overlook the fact that there is a long history of conflict surrounding the association of religion and policy. ${ }^{19}$ If, as sociologist José Casanova describes, "globalization also undermines the model of territorially based national religion or culture," ${ }^{20}$ and if religious rituals and beliefs "serve the cause of social integration by re-creating the bonds of solidarity of the imagined community," ${ }^{21}$ then whose community is socially integrated and recreated through faithbased policies in a global age? Whose assumptions and sensibilities integrate religion with government? In the following sections, I consider how new policies of faith-government partnership embed older models of modernization and development. I unpack the logic of encompassment by which rational-secular and sacred authority are mutually defined in the language of faith-based educational policy; I examine how the WFDD and U.S. faith-based policies portray a

15. See generally Émile Durkheim, The Elementary Forms of the Religious Life: A Study in Religious Sociolocy (Joseph Ward Swain trans., 1915) (describing Durkheim's views about faith).

16. Interviews conducted with Churches of Christ missionaries in Tanzania (June 18-19, 2002) and with Churches of Christ faculty in the United States (March $4 \& 7,2003$ ).

17. Field Research.

18. Dipesh Chakrabarty, Provincializing Europe: Postcolonial Thought and Historical Difference 16 (2000).

19. See generally Tomaž Mastnak, Crusading Peace: Christendom, the Muslim World, and Western Political Order (2002) (describing this long history of conflict). See also Conor Cruise O'Brien, God Land: Reflections on Religion and Nationalism (1988).

20. Casanova, supra note 11 , at 425.

21. Id. at 421 . 
simplistic picture of religion that reinstates their development missions within religion's frames; and I draw on field research to illustrate how, through the Churches of Christ's work in Tanzania, faith-based educational initiatives are subject to controversy.

\section{WFDD, USAID Faith-Based Initiatives, and Missionaries' Work}

Statements of ideals in faith-based initiatives have a characteristic textual form, one in which "religion" and "the secular" not only occupy a common ground but operate by a logic of mutual encompassment: a logic by which religious-moral ideals supercede and transform the secular state; and then a logic that reinstates rational-secular authority, in the form of faith-based governance, as a higher-order value that, in turn, encompasses religion and faith-based initiatives. ${ }^{22}$ In other words, WFDD and OFBCI faith-based policies raise religion to a higher ground and then replace religion within the parameters of secular governance. This logic of encompassment is evident in the way policy statements encircle images of poverty, defense, and violence, with promises of humanitarianism. Images of citizen-soldiers, armies of compassion, and missionary-citizens pepper U.S. presidential speeches and White House documents ${ }^{23}$ and images of perfect communication and a borderless world prevail in WFDD statements of purpose. ${ }^{24}$ In a July 2003 speech to a group of faith-based and community leaders, for instance, President Bush announced, "Really what we're doing is we're signing up the armies of compassion, which already exist, and saying, 'What can we do to help you fulfill your calling and your mission?' That's really what we're doing." 25 And in answer to a question posed on the WFDD web site, a policy writer for the WFDD wrote, "The term 'Dialogue' in

22. See Nira Yuval-Davis \& Pnina Werbner, Introduction: Women and the New Discourse, in Women, Citizenship, and Difference 10 (Nira Yuval-Davis \& Pnina Werbner eds., 1999) (stating that the logic of encompassment denotes "a hierarchy of values, the higher value encompassing an opposed value ranked below it").

23. For U.S. Presidential speeches and White House documents, see http://www. whitehouse.gov/government/fbci/ (last visited Dec. 6, 2004).

24. See The World Bank Group, supra note 4.

25. President George W. Bush, Remarks by the President to Urban Leaders (July 16, 2003), available at http://whitehouse.gov/news/releases/2003/07/20030716-2.html (last visited Aug. 31, 2004). 
the WFDD title... reflects the central purpose: to use dialogue to bridge the gulf of understanding separating development and faith institutions." ${ }^{26}$

"Rallying the armies" and "bridging the gulf" are mobilizing metaphors for OFBCI and the WFDD, respectively. The U.S. version evokes crusading peace while the WFDD version suggests ecumenism. "Rallying the armies," for instance, refers sometimes to the need to mobilize political support for U.S. federal legislation, including the proposed 2001 Armies of Compassion Bill ${ }^{27}$ and its 2002 enacted successor, the Compassion Capital Fund (CCF) ${ }^{28}$ The former, President Bush describes, "removes unneeded barriers to government support for community and faith-based groups." 29 At other times, "rallying the armies" evokes a sense of moral community, as when in February 2003, President Bush described the United States as "blessed with virtually millions of good-hearted volunteers" and asked his audience "to rally the armies of compassion" and "apply the great compassion of our people to the deepest problems of this country." ${ }^{30}$

"Bridging the gulf of understanding" likewise has a rhetorical effect that is broader than its specific meaning. The phrase references the interstitial place between different faith groups and between faith groups and governments. It focuses attention on the "space between" not on the "shores" or "territories" of different peoples. In creating neutral space, the WFDD takes a pragmatic approach that is in keeping with its leaders' vision of efficiency. In his address at the Interfaith Conference of Metropolitan Washington, Wolfensohn asked, "How could one think of addressing the questions of education and health in sub-Saharan Africa, with forty-seven countries and nearly 600 million people, without talking to the faiths that account for about half the education and half the health care in the continent of Africa?"31 Wolfensohn suggests not only the

26. World Faiths Development Dialogue, Development Dialogue, at http://wbln0018.worldbank. org/developmentdialogue/developmentdialogueweb.nsf/weblinks/YEON-5G4MTK? OpenDocument (last modified Nov. 2003).

27. See, e.g., Letter from President George W. Bush to Senate Majority Leader and Senate Republican Leader (Nov. 7, 2001), available at http:/www.whitehouse.gov/news/releases/2001/11/ 20011108-2.html (last visited Sept. 1, 2004).

28. See, e.g., Press Release, White House Office of the Press Secretary, The Compassion Capital Fund and the Faith- and Community-Based Initiative (June 5, 2002), available at http://www. whitehouse.gov/news/releases/2002/06/print/20020605-9.html (last visited Sept. 1, 2004).

29. Bush, supra note 14.

30. President George W. Bush, Address at the Opryland Hotel (Feb. 10, 2003), available at http:// whitehouse.gov/news/releases/2003/02/print/20030210-1.html (last visited Sept. 1, 2004).

31. Wolfensohn \& Carey, supra note 2. 
importance of strategies of community-building and cooperation, but also the importance of principles of diplomacy and efficiency.

Discursively, "rallying the armies" and "bridging the gulf" conjoin and subsume religion and politics within a framework of government policy. They encourage the integration of power across different domains and bring religion into the public sphere-a process that José Casanova refers to as the "deprivatization" of religion..$^{32}$ The images also evoke and promote what Gilles Deleuze has called "continual state control," ${ }^{33}$ the seamless integration of other-thangovernment operations into the operations of the state. However, in pulling together domains typically kept apart, faith-based initiatives reassert state-secular governance. The logic of policy allows that religion supercedes and encompasses government but that government in the end serves as a check and balance on religion. "Sadly," Wolfensohn stated at the 2004 Interfaith Conference, "some of the faiths let us down. Extremism in many faiths locks out the real essence of those faiths." ${ }^{34}$ His remarks show how faith-based policy excludes certain kinds of religious fundamentalism.

To counteract the threat of "extremism" and to demonstrate a more moderate hand, governing institutions, while welcoming faith groups, place at least nominal restrictions on faith groups' work. This is evidenced by the reiteration of a "no proselytizing" rule in faith-based policy. An OFBCI document on "Dos and Don'ts for Faith-Based Organizations," for instance, notes that a "faith-based organization should take steps to ensure that its inherently religious activities, such as religious worship, instruction, or proselytization, are separate-in time or location-from the government-funded services that it offers." ${ }^{5}$ More recently, President Bush announced his belief "that [these] groups should be allowed to access social service grants, so long as they don't proselytize, or exclude somebody simply because they don't share a certain faith. ${ }^{36}$ Likewise, World Bank descriptions of faith-based programs emphasize efficiency of delivery over groups' religious messages ${ }^{37}$ and the

32. See José Casanova, Public Religions in the Modern World 65-66 (1994).

33. See Gilles Deleuze, Foucault 76 (1986).

34. Wolfensohn \& Carey, supra note 2.

35. Office of Faith-Based and Community Initiatives, supra note 9.

36. Bush, supra note 7.

37. See Wolfensohn \& Carey, supra note 2. 
WFDD reiterates that their interests lie in matters of ethics and justice, not in theology or fundamentals. ${ }^{38}$

Of course, what constitutes a religious message is itself open to interpretation; and religious groups' involvement in public education presents a fascinating paradox. On the one hand, religious groups are not permitted to teach openly about Christianity in public schools $;^{39}$ yet on the other hand, their mode of instruction involves daily rituals that create conditions for religious conversion. ${ }^{40}$ For example, U.S. Churches of Christ missionaries working in Tanzania encourage students to pray quietly at the beginning of each day. ${ }^{41}$ Missionaries do not insist upon Christian prayer, but present it as one option. ${ }^{42}$ In public school classes, missionaries use the biblical creation story to teach days of the week and numeracy. ${ }^{43}$ Students enact the creation story and other Bible lessons in a skit for other students. ${ }^{44}$

The distinction between teaching and preaching is often the subject of intense debate. "Kneel down and pray, and you will believe," allegedly said Blaise Pascal, echoing Aristotle and suggesting that the physical practice of ritual enacts its own sense of knowledge through embodiment. ${ }^{45}$ As the following information from my field research illustrates, faith groups and non-faith groups alike hold a range of views about what constitutes preaching, versus what constitutes teaching. Like the WFDD and the OFBCI, the members of the Churches of Christ believe that hope and humanity supercede cultural differ-

38. See World Faith Development Dialogue, Main Page, at http://www.wfdd.org.uk (last visited Jan. 27, 2005).

39. See Office of Faith-Based and Community Initiatives, supra note 9 (pertaining to religious groups in U.S. public schools); see also Florens D.A.M. Luoga, The Tanzanian Bill of Rights, in Fundamental Rights and Freedoms in Tanzania 37-46 (1998) (pertaining to the Tanzanian Constitution). However, in Tanzania, religious groups may proselytize in specifically designated religion classes, and only to students who already identify with the religious view being preached. Interview with Tanzanian Ministry of Education and Culture Officer (June 10, 2002).

40. This observation comes from field research conducted in Tanzania, June and July 2002. See also Talal Asad, Formations of the Secular: Christianity, Islam, Modernity 183-84 (2003).

41. Field Research.

42. 1 .

43. Id.

44. Id.

45. See also Talal Asad, Genealogies of Religion: Discipline and Reasons of Power in Christianity and Islam 35 (1993); Pierre Bourdieu, Outline of a Theory of Practice 114-20 (1977) (recognizing the importance of ritual practice as restoring the internal logic of a symbolism to its practical necessity by relating it to the real conditions of its genesis). 
ences at the local and national levels. However, instead of conceptualizing that government and faith are mutually entwined, the Churches of Christ see religion as superceding and encompassing government. I explore this view, as different from $\mathrm{OFBCl}$ and WFDD views, toward the end of this essay.

\section{A Faith Group's Work}

Over the past ten years, evangelists from the United States have involved themselves increasingly in the formal education of young Africans. Criticized in the late 1990s by African government officials for having done too little to advance development, U.S. evangelists of independent Protestant churches have begun to turn their attention to basic education. ${ }^{46}$ The World Christian Encyclopedia notes of Tanzania, for example, that atheists are "mainly intellectuals" and that their numbers increased in the $1990 \mathrm{~s} .{ }^{47}$ Such comments invigorate evangelical Christian activity in the realm of education. ${ }^{48}$

Religious groups' involvement in African education is not new. Colonial governments relied, in part, on Christian missions to provide basic education; early independent governments generally permitted religion to be taught as a formal subject in primary schools. Today, many religious organizations and schools cooperate without any formal partnering. Many projects predate new faith-government policies, including the World Bank-funded Aga Khan Foundation madrasa pre-school program that started in East Africa in the 1980s and USAID-funded projects that have been coordinated by Catholic Relief Services and Lutheran World Relief since the $1970 \mathrm{~s} .{ }^{49}$ However, while a long history of faith-government partnerships endures, today's faith-based policies include a new community; not only religious groups' umbrella relief organizations but also grassroots religious groups and community organizations. In the United States, this shift invites national political engagement with an independent-evangelical Christian commu-

46. Interview with Churches of Christ professor of religion (Mar. 23, 2003).

47. David B. Barretr et al., I World Christian Encyclopedia: A comparative Survey of Religions in the Modern World 729 (2d ed. 2001).

48. Interview with Churches of Christ professor of religion (Mar. 23, 2003).

49. USAID Office of Private Voluntary Cooperation-American Schools and Hospitals Abroad, Armies of Compassion Alleviating Human Suffering Abroad, at http://www.said.gov/our_work/ cross-cutting_programs/private_voluntary_cooperation/pvoconf03_faithbasedslides.pdf (last visited Jan. 27, 2005). Cf. Marshall, supra note 1, at 346 (noting the International Labour Organisation and the United Nations have long worked with faith groups). 
nity. ${ }^{50}$ In WFDD terms, it supports the participation of religious groups in community development and poverty reduction: the WFDD "aims to see if there are ways in which the religious communities can contribute more vigorously through debate and action to bringing about an improvement for the poor." ${ }^{51}$

Among the most educationally active of U.S. evangelical Protestant groups in eastern Africa is the U.S. Churches of Christ, a conservative denomination influenced by the 1950s Assemblies of God "Discipling" movement. Not to be confused with the United Church of Christ, ${ }^{52}$ the U.S. Churches of Christ derive historically from the 1832 Stone-Campbell movement whose followers sought to reestablish a community of Christians as it existed in 30 A.D..$^{53}$ Churches of Christ members spurn centralized church hierarchy, noting that Jesus alone is head of the Christian community, and refer to themselves not as a denomination but as 'churches' in the plural and sometimes in the lower case to symbolize humility. ${ }^{54}$ As described on the Churches of Christ's ministries webpage, members view the Bible as the "basic textbook of the church" and "follow the teachings of Jesus Christ and his holy Apostles, and not the teachings of man." ${ }^{56}$ Believing that the Bible is "the only possible common denominator upon which most, if not all, of the God-fearing people of the land can unite" ${ }^{57}$ and that the Bible is the "only sure guide to heaven" 58 members of the Churches of Christ use the Bible to teach nonreligious subjects and to infuse religious principles into the activities of daily life.

50. See, e.g., USAID Office of Private Voluntary Cooperation-American Schools and Hospitals Abroad, supra note 49 (contrasting "well known organizations such as Catholic Relief Services and Lutheran World Relief" with "faith-based and community-based groups" who are newly encouraged to compete for federal funds).

51. World Faiths Development Dialogue, About WFDD: What We Are, at http:// www.wfdd.org.uk/aboutus.html (last visited Jan. 27, 2005).

52. The United Church of Christ is an ecumenical union of congregational and reformed churches founded in the United States in 1957 and considered part of "mainline" Protestantism.

53. See generally Richard T. Hughes, Reviving the Ancient Faith: The Story of the Churches of Christ in America (1995); Dale A. Jorgenson, Theological and Aesthetic Roots in the Stone-Campbell Movement (1989).

54. Interview with Churches of Christ minister (June 18, 2002).

55. Batsell Barrett Baxter, Who Are the Churches of Christ and What Do They Believe in?, at http:// church-of-christ.org/who.html (last accessed Sept. 24, 2004). Also reported by Churches of Christ minister in an interview conducted June 18, 2002.

56. Internet Ministries, The Churches of Christ, at http://www.church-of-christ.org (last accessed Aug. 25, 2004).

57. Baxter, supra note 55.

58. Id. 
U.S. Churches of Christ members believe they face a particular challenge in Tanzania; Islamic groups' growing claims on schools and government. ${ }^{59}$ Many eastern African teachers, both Christian and Muslim, acknowledge the colonial Christian legacy in national systems of education, and some Islamic groups maintain that Muslim students are at a disadvantage in schools that reflect a Christian legacy. ${ }^{60}$ Embracing policy ideals of partnership and local governance, some Muslim leaders in the community would like to see the previously Muslimowned primary schools returned to Muslim leadership. ${ }^{61}$ Whereas policy statements about faith-based partnerships focus on the harmonious integration of faith groups and governments, tensions between different religious groups and some groups' feelings of exclusion suggest other possibilities.

\section{A. Mission Moshi: Getting Back to a Better Future}

"Mission Moshi" is located in the capital city of Kilimanjaro Region, in Tanzania. Founded by a group of U.S. missionaries who had been working in Kenya for many years, the mission relies on Christian college students from the United States to staff English language programs during the months of June and July. In Moshi, the Churches of Christ run an English language program called "Let's Start Talking" and another English language program in two public (government-owned) primary schools. One of the reasons U.S. missionaries give for teaching English in primary schools is that speaking English is a necessary skill for participating in a global economy. ${ }^{62}$ "English, you know, it's the universal language," said one missionary when asked why the group focuses on English language instruction. It is a language you need "when you're dealing with business and great economies. The number one language is English." Not unlike the

59. Interviews with various U.S. Churches of Christ missionaries working in Tanzania (2002); Interviews with various Mission Studies faculty members employed by Churches of Christ universities in the United States (2003).

60. See, e.g., Mohamed Said, Intricacies and Intrigues in Tanzania: The Question of Muslim Stagnation in Education, at http://www.islamtz.org/nyaraka/Elimu2.html (last visited Aug. 9, 2004); see also C. C. Stewart, Islam, in The Colonial Moment in Africa: Essays on the Movement of Minds and Materials, 1900-1940, at 191 (Andrew Roberts ed., 1990) (discussing the history of tensions between Christians and Muslims in the arena of education).

61. Field Research; see also Amy Stambach, Faith in Schools: Toward an Ethnography of Education, Religion, and the State, in Social Analysis: The International Journal of Social and Cultural Practice, Fall 48(3).

62. Interviews conducted with U.S. missionaries working in Tanzania (June and July 2002). 
World Bank's idea that faith-groups should engage in global "dialogue," this missionary believes that knowing English will make it possible to talk and to do business with the rest of the world. "Since this country is so poor," he reasons, "the way that Tanzanians can get back to a better economy is to learn some more English and to expand their economy to other countries."

In arguing that "Tanzanians can get back to a better economy," missionaries consider that the future lies in Africans' engagement with a global political economy. Missionaries generally argue that Africans must embrace what they have already missed: the opportunity to participate in a global economy and to become members of a Christian world. Ujamaa or African socialist policies of the first president, Julius Nyerere, missionaries describe, isolated Tanzanians from capitalism, plunged Tanzanians into poverty, and led to the growth of a cohort of atheist intellectuals, many of them anti-capitalist because they were Chinese educated. ${ }^{63}$ Nyerere's socialism, to Churches of Christ missionaries, was cold-hearted and a-spiritual. ${ }^{64}$ In a particularly vivid image that decries the marginalization of religious groups (of any faith) under ujamaa, one U.S. missionary remarked that one of the schools "in which we work, before ujamaa, was a Muslim school. [Then, in 1969, when the socialist government nationalized all private schools,] it was confiscated by the government. They cut the quarter moon off the gate, and it became a government school. At the end of ujamaa," the missionary continued, referring to the Tanzanian government's liberalizing policies of the late 1980s and 1990s, "apparently the Muslim community has been pushing-they wanted their school back." 65 The assembly hall in which the missionaries hold classes was once the site of a madarasa and Q'ranic prayer and to some Muslims remains a sacred space. ${ }^{66}$

"Getting back to a better economy" in Churches of Christ discourse means moving ahead in a particular way. Churches of Christ discourse is ambivalent about whether the future is fully evangelical-Christian or interdenominational, or whether if, even more broadly, it is multireligious or pluralistic. Much like the policy language of the WFDD and OFBCI, Churches of Christ discourse employs images of ecumenism and crusade. It locates religion within the state and then surrounds the state with the authority of religion. Education provides a

63. Interview with Churches of Christ missionary (June 19, 2002).

64. Id.

65. Id.

66. Conversation with Tanzanian residents (June 30, 2002). 
means for leveling economic imbalances between the United States and countries in Africa, and religion provides a means for re-enlivening a political economy broken by "faithless" and economically regressive socialism. However, instead of seeking to create an interstitial space between different faiths and different governments, as the WFDD does, and instead of "rallying the armies" in the interest of linking national and foreign policies, as does recent USAID faithbased policy, missionary discourse in this location places a particular vision of Christian faith on a higher plane than government, and on a higher plane than other religions, including "mainline" Protestantism.

As a precondition to their teaching in Tanzanian public schools, the Tanzanian government stipulated that missionaries may not proselytize, may not reference the New Testament, and may not mention Jesus in any of their teachings at the schools. ${ }^{67}$ The Regional Education Officer told the missionaries that doing so might offend non-Christians, particularly Muslims. ${ }^{68}$ However, "as part of being a missionary," a U.S. university student remarked,

we feel that since we're going to be teaching in [Tanzanian] schools, we're going to be talking about the Word of God, and hopefully, by doing that, whoever we talk to, whether they're Hindu, Muslim, Christian, Catholic, no matter what their religion is, even if they don't have a religion, maybe we can make a connection and someone will come to Christ using that. ${ }^{69}$

Asked whether in "talking about the Word of God" Churches of Christ missionaries were not inherently preaching, a leader of the missionary group responded by describing the church's "Jesus method."

We now do what we call the Jesus method which says that fifty percent of Jesus' time was spent doing Kingdom of God churchy things, teaching, and half of his time was spent touching, weeping, helping, whatever. So we really think that a balanced missionary ought to spend fifty percent of his time in regard to doing

67. Interviews with Churches of Christ missionaries (June 18-19, 2002); interviews with Tanzanian education officials (June 17, 2002).

68. Interview with Churches of Christ missionary (June 19,2002).

69. Interview with Churches of Christ missionary (June 13, 2002). 
some kind of community development. And fifty percent of his time ought to be spent in church development. ${ }^{70}$

The Jesus method of "missionization" meshes well with faith-based policy initiatives. It involves teaching without overtly proselytizing and operating from a vision of community development and social justice. The Jesus method accords with Wolfensohn's vision of "something higher" that "stands for morality, for ethics, for faith, for equity, for justice, for spirituality." It shares President George W. Bush's ideal that "miracles" happen not by force but "because loving souls take time out of their lives to spread compassion and love" and to initiate change "from the bottom up." 72

Because the sacred and secular are given equal time, the Jesus method, in general, conforms in principle with the ideals of liberal-secular public policy. It fits well with the prevailing policy view that the sacred and secular are separate but complementary, and that faith groups' job, like governments', is to reduce poverty and alleviate human suffering. Articulating the Jesus method in another way, one of the above missionary's colleagues said, "In public settings, we do secular things but don't evangelize. We divide our time equally between the sacred and the secular."73

However, the Jesus method is more complicated and varied 'on the ground' than is evident in missionary remarks or in faith-based policies. First, these missionaries use Old Testament stories to teach one of several daily themes. They use the story of Joseph's technicolored coat to teach English words for colors; they use the story of Noah's Ark to teach the English names of animals; and they use the creation story to teach English words for numbers. ${ }^{74}$ The missionaries do not reference Jesus or use any lessons from the New Testament, and they do not ask students directly to engage with questions about religion. ${ }^{75}$ Yet the Jesus method arguably creates the conditions for religious engagement and conversation. It does not primarily involve the cognitive grasping of information about religion but it introduces stories' basic points and creates a space for Tanzanian students to inquire further. As one of the missionaries noted, "If one of the

70. Interview with Churches of Christ missionary (June 19, 2002).

71. Wolfensohn, supra note 3 .

72. Bush, supra note 7.

73. Paraphrased from conversation (June 19, 2002).

74. Field Research.

75. Id. 
students or one of their African teachers asked a question ... and if they asked, 'Well, what do you do? What do you believe?' we could tell them. But they had to initiate the conversation, we couldn't start it." When asked, "Do they ask?" she answered, "Oh yeah."76

Additionally, the introduction of Old Testament stories sets the stage for a second kind of encounter: the invitation of American missionaries into students' homes, where missionaries meet students' families and open doors for yearround missionaries. "We've had so many children invite us into their homes... and by doing that, we can meet their parents and their families." "77 Whereas, in the first instance, the WFDD and OFBCI envision faith-based work as a matter of eradicating poverty, members of this group, while not dismissing the importance of contributing to economic development in the region, envision that their work will augment their numbers in church.

A recurring theme in missionaries' descriptions is the conversion of a Muslim school boy to Christianity. Many versions note that the student transformed from saying "I cannot be around you because I'm Muslim" to serving communion in church. ${ }^{78}$ Thus, even though a predominant view within faith-based policies is that education is a matter of technical training, and notwithstanding that these missionaries see English training as a means toward global economic and political participation, the Churches of Christ missionaries also envision that their work leads students to religious conversion.

\section{B. Politics}

In considering that development is as much an economic as spiritual transformation, Churches of Christ missionaries also remark-although not often explicitly - that their work may be politically controversial. By most accounts, the first year (1999) of the mission-led English program was well received-so well received, that by February 2000, the previously Muslim-owned schools initiated an "English only" track during the regular school year. Primary school students studied and spoke in English, not in Kiswahili, the national language of Tanzania. However, by August 2000, seven months after starting the English

76. Interview with Churches of Christ missionary (June 13, 2002).

77. Id.

78. Field Research; conversations with Churches of Christ missionaries. 
track, the school dropped the program "to maintain peace," said one of the head teachers.

Because 2000 was an election year, various political parties mobilized to promote and elect their candidates. Large trucks careened around the streets of Moshi, blaring campaign ads and pulsating loud music. ${ }^{79}$ The Chama Cha Mapinduzi (CCM) held most incumbent positions; its strongest challenger for some positions was the Civic United Front (CUF). CCM was known as a Christian party, since many, though not all, elected CCM members self-identified as Christian; CUF was identified as a Muslim party, since some of its funding supposedly came from Islamist sources. In an interview conducted in July 2002, one teacher described CUF this way:

CUF is the, ah, Muslim party. It's a very harsh one. And in fact, if you're not careful with them, their people are very harmful. I think you understand the issue and so forth. Yeah, they are in that way. Their movement and so forth. ${ }^{80}$

This teacher also said that during the campaign,

[p]oliticians were busy trying to win teachers and so forth. ... And the opposition, CUF, was using our school to their own political advantage. They were challenging CCM party members to take a stand on our school. [CUF was saying that CCM] was selling Tanzanian schools to outsiders and so forth. That was untrue. So that was the issue. ${ }^{81}$

In the early stages of partnering with American missionaries, Muslim parents who were engaged with the school generally supported the school's efforts to initiate English medium. But in the context of national election campaigns, the partnership became clouded with competition for seats in government. It also became conflated with the interests of private primary schools. Administrators of private schools-themselves for-profit operations-worried that free,

79. Id.

80. Interview conducted with a Tanzanian school teacher (June 17, 2002).

81. Id. 
public English education would drain students from their classes. To quote the above-mentioned teacher again:

The conflict in fact was not caused by the Muslims; it was caused by private English medium schools. You know, [critics of our English medium program] told us if our [public] school was going to be a free English medium, theirs is a private one and people have to pay, then they won't get market. So [these critics] associated with the conflicts of making sure that [our English medium] school was no longer going on. That was the main reason we shut down.... Now, this group [of opponents to our English program] was run by members of those private English academy schools along with some of [the] Muslims who are very close to this school. Yes. Impressing them [to] dislike our school to become an English medium [i.e., encouraging Muslim parents to prevent the school from supporting an English track]. ${ }^{82}$

The calendar-year English medium program was shut down as a result of this politicking. ${ }^{83}$ The public school, partnered with the Churches of Christ missionaries, came face-to-face with the private school sector, which was mainly run by Christians, who partnered with a Muslim-associated political party. ${ }^{84}$

Notwithstanding the images of harmonious dialogue and cooperation found in WFDD and OFBCI policies, this faith group's work in Tanzanian public schools is associated by some with controversy. This faith group's involvement illustrates that faith-based development work is not wholly circumscribed or guided by governmental policies. Rather, while it falls within the realm of policy vision in remaining outside the reaches of formal politics, this faith group's work is drawn into the currents of local and national political-religious struggles. Indeed, some members of the Churches of Christ maintained that the mission's work was drawn into politics by divine intervention ${ }^{85}$ Churches of Christ missionaries explained that they do not always understand the effects of

82. Id.

83. Id.

84. Id.

85. Conversation with Churches of Christ missionaries in the course of conducting observations of missionaries' work in the two Tanzanian schools (June and July 2002). 
their work but trust that it is useful. "I would just like to bring people the Word and answer their questions to the best of my ability," said one missionary, describing herself as an imperfect vehicle for conveying a greater message. ${ }^{86}$

Perhaps the framing of development work on a higher, spiritual plane is why members of this group are ambivalent in speaking about a Christian nation or government but are more comfortable in talking about a Christian global world. Whereas faith-based policy statements and this group's mission both embrace a "higher order" of ethical social engagement, members of the Churches of Christ envision that their work supercedes and encompasses that of government and of international organizations such as the World Bank. A cluster of recent articles in Leaven, a publication of Ministry for Restoration Heritage Churches—of which the Churches of Christ is one-gives some evidence of this. It addresses the question of whether, and if so how, Christians should engage with and work in government. One author, a director of missions at an evangelical Christian university in Tennessee, posits that a hypothetical second-century Christian soldier is asked by fellow Christians: "Why have you chosen to be a soldier when you have such a higher calling?" ${ }^{87}$ The author's message is that while one may do the work of government and act as a soldier on its behalf, Christians operate by a moral principle that may or may not be the same as government's. Today's world, the author states, must be lived in skeptically: "The voice of the early church shouts out to us, 'Be in the world, but not of the world." $" 88$

\section{Education, Religion, and Globalization}

Many observers have remarked that Christianity embeds a universalizing discourse that, like globalization, contributes to the deterritorialization of nationstates and to the restaging of human life on the territory of the globe. ${ }^{89}$ "By undermining the territorially-based fusion of state, market, nation, and civil soci-

86. Interview with Churches of Christ missionary (June 15, 2002).

87. Earl Lavender, The Early Church and Government, in Leaven: A Pubi.jcation of Ministry for Churches of the Restoration Heritage 10(2), at 62, 65 (2002).

88. Id. at 66.

89. See Paul Freston, The Transnationalism of Brazilian Pentecostalism: The Universal Church of the Kingdom of God, in Between Babel and Pentecost: Transnational Pentecostalism in Africa and Latin America 196, 196-215 (André Corten \& Ruth Marshall-Fratani eds., 2001) [hereinafter Between Babel and Pentecost]; Karla Poewe, Introduction: The Nature, Globality, and History of Charismatic Christianity, in Charismatic Christianity in a Global Culture 1 (Karla Poewe ed., 1994). 
ety," Casanova notes in an essay on religion, "globalization ... undermines the model of territorially-based national religion or culture." ${ }^{.90}$ Certainly postenlightenment ideas of pluralism have undone older European ideas of national churches controlled by absolutist states; ${ }^{91}$ and international support for human rights and for free and fair trade, emergent in the last decades of the twentieth century, contribute to a misalignment of people and a particular place. ${ }^{92} \mathrm{But}$, related to what he earlier called the deprivatization of religion, ${ }^{93}$ Casanova brilliantly states, "the old gods and the old religions [are gaining] new life by becoming the carriers of the process of sacralization of humanity." Religion is seen in these early days of the millennium as carrying the possibility not only of elevating people beyond local worlds but of integrating world regions on a higher moral and spiritual plane. Evangelical Christianity universalizes humanity and gives humanity suprahuman meaning-vast cultural and historical variations notwithstanding. ${ }^{95}$ Perhaps this is why faith-based initiatives have taken on such urgency in a post-September 11 th period in international and U.S. policy discourse. Both U.S. and World Bank descriptions evoke September 11 th as a pivotal date. "September 11,2001 may well have marked the start of an important paradigm shift in thinking about the links between globalization, international relations, and religion," reads a statement on the WFDD web site. ${ }^{96}$ "Before September 11th, 2001, we thought oceans would protect us forever... But all that changed on that fateful day.... We're called to defend our nation and to lead the world to peace, and we will meet both challenges with courage and with confidence[,]" remarked U.S. President George W. Bush to an audience in Nashville, Tennessee. ${ }^{97}$ Much as "occult economies" arise in re-

90. Casanova, supra note 11 , at 425.

91. See id. at 424.

92. At least, these ideas have contributed to the misalignment of transnational educated elite and the migrant poor.

93. Casanova, supra note 32 , at $65-66$.

94. Casanova, supra note 11 , at 430.

95. However, Hurbon's insight that "conversion does not imply the obliteration of local values and traditions" should not be dismissed. See Laënnec Hurbon, Pentecostalism and Transnationalisation in the Caribbean, in Between Babel and Pentecost, supra note 89, at 124, 138.

96. World Faiths Development Dialogue, supra note 9.

97. Bush, supra note 14. 
sponse to millennial capitalism, so it appears that faith-based initiatives emerge as an antidote to the political-economic ills of globalization. ${ }^{98}$

However, missing from Casanova's picture, and suggested in the WFDD and OFBCI statements above, is the point that nation-states and international organizations are themselves trying to reintegrate their development missions within religion's frames, and that education is a critical site upon which the "sacred" and the "secular" are newly entwined. Faith-based policies and the Churches of Christ's work suggest a renewal of engagement, albeit uneven, between governing bodies and religious organizations. It is not that religion is on the loose and the state is left ethically unmoored, as is sometimes suggested in discussions about "faithless" government; but rather that key policymakers and some elected officials seek to use education as a place to redefine principles of governance. Religion is used instrumentally among policymakers as a tool advancing development work, and education is conceived of as a site where the distinctions between preaching and teaching-or between proselytization and embodied witness-are blurred. ${ }^{99}$

Like religion, education, in the language and imagery of policy discourse, is a domain of infinite, imaginative possibility. Working in schools provides a chance, from the vantage point of policymakers and evangelical Christians, to rebuild a "shattered" global culture on a spiritually higher plane. It provides a chance to work from the ground up, through the minds and bodies of children, to build a community that some would hope is global, not only politically and economically, but also in a spiritual vein. Education seldom receives much attention in discussions about globalization or about religion; yet education-schooling, specifically, because its structures are more or less cross-regionally standardized-situates students simultaneously at junctures global and local. Schools are, to borrow Robertson's guttural term, places for the staging of "glocality," the simultaneous production of "the universal" and "the particular," of "the whole" and "the part." 100

98. See Jean Comaroff \& John L. Comaroff, Millennial Capitalism: First Thoughts on a Second Coming, 12 Pub. Culture 291, 310-18 (2000) (discussing occult economies); Transparency and Conspiracy: Ethnographies of Suspicion in the New World Order (Harry G. West \& Todd Sanders eds., 2003) (discussing a related issue of state power).

99. See Stambach, supra note 61 (discussing how U.S. policy discourse blurs the distinction between preaching and teaching-or between proselytization and embodied witness, as the distinction is made by John Towey, director of the U.S. OFBCI).

100. See Roland Robertson, Globalization: Social Theory and Global Culture (1992). 
They are places where, despite their uniformity, one can observe the polycentric production of globalization. ${ }^{101}$

A shortcoming of some studies of education and globalization has been to confuse the manifest uniformity of schools' outward forms with evidence of an "internal" cultural convergence toward a global culture. When Kelly Stromquist and Karen Monkman write, for instance, that "globalization fosters a greater synchronization of demands as well as a greater similarity in taste," or that local cultures are trying to "retain their identity and, in some cases, even to rediscover it," 102 their point raises the questions: what are those "tastes" and "identities," and in relation to what are they being reimagined? - questions similar to those Talal Asad asks with reference to religion's appeal in the public sphere ${ }^{103}$ and that Kathleen Hall addresses with regard to education. ${ }^{104}$ Similarly, when other researchers argue that "nation-states have become increasingly internationalized" or that states have lost political autonomy and have become irrelevant to citizens' governance, ${ }^{105}$ the point is well made and yet also raises more questions about how state authority is reconfigured.

If the case involving this faith-based group in these public Tanzanian schools under conditions of multiparty politics and privatization is any indication, state authority in education is not so much eroded or supplanted as it is matched by "horizontal contemporaries" that press up against the state and give it new reason for revival. ${ }^{106}$ In view of the fact that the government of Tanzania recently required all education-oriented nongovernmental organizationswhich includes faith-based and community groups-to re-register with the

101. See, eg., Local Meanings, Global Schooling: Anthropology and World Culture THEORY (Kathryn Anderson-Levitt ed., 2003) (introducing the idea of schools moving "toward a single model").

102. Nelly P. Stromquist \& Karen Monkman, Defining Globalization and Assessing Its Implications on Knowledge and Education, in Globalization and Education: Integration and Contestation Across Cultures 3, 7 (Nelly P. Stromquist \& Karen Monkman eds., 2000).

103. See ASAD, supra note 40, at 183-84.

104. See Kathleen Hall, Understanding Educational Processes in an Era of Globalization: The View from Anthropology and Cultural Studies, in Issues in Education Research: Problems and PossibiLITIEs 121 (Ellen Condliffe Lagemann \& Lee S. Shulman eds., 1999).

105. Nicholas C. Burbules \& Carlos Alberto Torres, Globalization and Education: An Introduction, in Globalization and Education: Critical Perspectives 1-26 (Nicholas C. Burbules \& Carlos Alberto Torres eds., 2000).

106. See James Ferguson \& Akhil Gupta, Spatializing States: Toward an Ethnography of Neoliberal Governmentality, 29 Ам. ЕтнNoLoGist 981, 994 (2002). 
state, and in view of the fact that it has revoked the visas of foreign missionaries, arrested some, and in some cases deported missionaries from the country ${ }^{107}$ - the continuing presence of the state in governing and monitoring state borders seems profoundly evident.

\section{Conclusion}

The world is increasingly presented, in various realms, with a need to be rescued from the stratifying and often heartless forces of globalization. Whether the solution is to "rally the armies" or to "bridge the gulf," as U.S. and WFDD policy discourse present it, or to use the Jesus method of teaching as the Churches of Christ missionaries describe, religion is far more complicated and politicized than is generally acknowledged in faith-based policies. Certainly, schools' promise of global access matches well with religions' messages of universality; and the global scope of religion and education resonates well with the political-economic dimensions of globalization. Yet globalization, like religion and education, is rooted in a local groundedness. Understanding what the many and often competing contexts are is key to understanding the appeal, and controversies, surrounding religion, education, and globalization.

107. Personal observation (July 2002). 